Original Research Article

\title{
A cross sectional study of knowledge, practice and attitude of medical professionals regarding pharmacovigilance function
}

\author{
Kiran Rajendra Giri ${ }^{1}$, Kamlesh Manohar Palandurkar ${ }^{2 *}$, Reena Rajendra Giri ${ }^{3}$
}

\begin{abstract}
${ }^{1}$ Department of Pharmacology, ${ }^{2}$ Department of Biochemistry IMS BHU Varanasi, Uttar Pradesh Province, India ${ }^{3}$ Department of Pharmacology, GMC, Akola, Maharashtra, Province, India
\end{abstract}

Received: 26 June 2018

Revised: 31 July 2018

Accepted: 04 August 2018

*Correspondence to:

Dr. Kamlesh Manohar

Palandurkar,

Email: Kamleshpalandurkar187 @gmail.com

Copyright: (C) the author(s), publisher and licensee Medip Academy. This is an openaccess article distributed under the terms of the Creative Commons Attribution NonCommercial License, which permits unrestricted noncommercial use, distribution, and reproduction in any medium, provided the original work is properly cited.

\begin{abstract}
Background: Pharmacovigilance is of core importance for the prevention of adverse effect by signal generation. It developed as a science and Practice. Central database collecting international reports helpful in generating signals, improving safety profile, prevention of future adverse effects, thus provide a key data to national drug regulatory to make regulation. It is not only a science but act as a law and regulation. Underreporting of ADRs by healthcare professionals remains a major problem. Clinician's collaboration is needed to come up with the challenges of underreporting. Spontaneous reporting plays a cardinal role in Pharmacovigilance practice.

Methods: Cross Sectional, questioner-based study, 56- postgraduates, 42- first year,60- Second year, 35- Third year students of Institute of Medical Sciences were included with prior consent and Ethical committee permission. Structured pre-test questioner on, Knowledge-10, Attitude-02, Practice-06 were asked. Seminar was conducted on the 'Pharmacovigilance in India: current Scenario, Study material were distributed to students. Prior to seminar and one week after conduction of seminar again the questioner was distributed again, and the same study was conducted, the difference in the response and attitude after transformation of knowledge were recorded.

Results: After transformation of knowledge $77 \%$ JR responded that ADR and medication both should be reported which was earlier only $31 \% .80 \%$ JR replied that ADR should be reported as early as possible which was earlier $38 \%$. It indicates that transformation of knowledge is a pillar to bring the change in practise. $100 \%$ second year students responded that they have seen ADR reporting form which was only $30 \%$ before seminar.

Conclusions: Up gradation of Knowledge by seminar, research papers, awareness pamphlets, Apps will promote the reporting and will strengthen the signal generation systems.
\end{abstract}

Keywords: Attitude, Medical professional, Practice, Pharmacovigilance, Transformation of knowledge, Underreporting

\section{INTRODUCTION}

In an Era of Modern Medicine, everybody's life is touched with effects and side effects of medicines. Pharmacovigilance is of core importance for the prevention of adverse effect by signal generation. It developed as a science and Practice. Central database collecting international reports helpful in generating signals, improving safety profile, prevention of future adverse effects, thus provide a key data to national drug regulatory to make regulation. It is not only a science but act as a law and regulation, evolved in 1980's, in collaboration with WHO. In Medical colleges, adverse drug reporting centers are established for spreading awareness, detection of adverse effects. Online availability of Medicine, globalization came up with new challenges in the field of Medicine, such as counter fit drugs, Illegal sale, abundance of herbal and traditional medicine available with little instruction about drug and drug food 
interaction. ${ }^{1,2}$ Science and practice of Pharmacovigilance should acquiesce with new direction considering new challenges. $^{3}$

Government of India Launched the nationwide pharmacovigilance programme in $2010 .{ }^{1}$ Since $15^{\text {th }}$ April 2011 Indian Pharmacopoeia Commission is functioning as national co-ordinator centre for Pharmacovigilance programme of India. ${ }^{4}$

Expanding the Pharmacovigilance programme including 179 MCI approved teaching hospital identifying them as ADR monitoring centre. ${ }^{1}$ Institutional Pharmacovigilance Centre has played major role in improving public cognizance. ADRs are reported to National Coordination Centre via vigiflow a web based Individual case safety reports management system. ${ }^{4}$

Underreporting of ADRs by healthcare professionals remains a major problem. Clinician's collaboration is needed to come up with the challenges of underreporting. Some of the ADRs have classical findings but many of the ADRs early detection require expertise, perfervid observation. Experiences of previous cases helps in better judgment. Recently published study by Tandon VR, Mahajan $\mathrm{V}$ et al. data shows that average number of Individual case safety reports reported by their centres is 48.38, Active surveillance verses spontaneous reporting contribute $66.13 \%$ versus $33.86 \%$ of the total ADRS. ${ }^{5,6}$

To deal with underreporting is challenge. Various reasons lead to the underreporting amongst it few important are lack of awareness, ignorance, and lethargy, under confidence, inadequate risk perception, and insufficient training. ${ }^{5}$

In 2012 published systemic review data, concretely support the issue of underreporting. The median underreporting rate across the 37 studies was $94 \%$ (interquartile range $82-98 \%$ ). There was no significant difference in the median under-reporting rates calculated for general practice and hospital-based studies. Five of the ten general practice studies provided evidence of a higher median under-reporting rate for all ADRs compared with more serious or severe ADRs (95\% and $80 \%$, respectively). ${ }^{7}$

Spontaneous reporting plays a cardinal role in Pharmacovigilance practice. Signals have qualitative and Quantitative aspects. ${ }^{8}$ After receiving signals from practitioners or patients or pharmaceutical companies, it is the role of Pharmacovigilance center to analyse the report and inform the person concern in case of new ADRs.

Other sources of signals are prescription event monitoring, case-control surveillance and follow-up studies. A continuous systematic review of all combinations of drugs and suspected adverse reactions (ADRs) reported to a spontaneous reporting system, is necessary to optimize signal detection. ${ }^{9,10}$
The aim of the present study is critical assessment of the present scenario to identify problems and reasons of underreporting, transformation of knowledge and training to improve ADR reporting.

\section{Objectives}

- To assess the knowledge, attitude and practice of postgraduate and undergraduate students towards pharmacovigilance in tertiary care teaching hospital.

- To assess the effectiveness of education and training of pharmacovigilance.

\section{METHODS}

The design of this study was cross Sectional, questionerbased study, 56- postgraduates, 42- first year, 60- second year, 35- third year. The study site was Institute of Medical Sciences, Banaras Hindu University for the period of 3 months.

\section{Inclusion criteria}

- Students from Institute of Medical Sciences, BHU who gave consent for the study.

\section{Exclusion criteria}

- Not willing to participate or absent during the course of study.

\section{Structured pre-test questioner on}

- Knowledge-10

- Attitude-02

- Practice-06

\section{Questioner validation}

Draft made and circulated in research team, suggestion taken, in pilot study questioner validation of 30 students of IMS BHU had done. Cronbach alpha value was calculated

Time: 30 min time given to each participant for answering the questioner.

\section{Content of Slide presentation}

1. All theoretical aspect as well as necessary practical knowledge to facilitate the reporting of ADRs

2. Training of filling ADR reporting form

\section{Content of study material provided to the participants}

All theoretical aspect as well as necessary knowledge to facilitate the reporting of ADRS was included in the study material, study material was provided to all participants after one week of the distribution of study again the questioner was distributed to check the improvement in understanding, attitude and knowledge. 


\section{RESULTS}

Several questions were asked to the junior resident, first year, second year and third year students, related to practice, knowledge and attitude of pharmacovigilance, 40 resident attended the seminar conducted on Pharmacovigilance in India. Current Scenario, 16 residents were absent, second year students during their regular pharmacology classes and to first and third year students before seminar conduction, 58 second year, 37 first year and 22 final year student attended the seminar conducted on 'Pharmacovigilance in India: current scenario, all the resident including absent students were contacted and provided with study material and ADR reporting form on pharmacovigilance, one week after conduction of seminar again the questioner were distribute and the same study was conducted, the difference in the response and attitude after transformation of knowledge is as follows, Table 1 indicate the change in practise after transformation of knowledge, after seminar 95\% JR, 100\% second year students have seen the ADR reporting form and know the essential details required to fill ADR form which is the first step towards reporting.

Table 1: Practice.

\begin{tabular}{|c|c|c|c|c|c|c|c|c|c|}
\hline \multirow[t]{2}{*}{ Question } & \multirow[t]{2}{*}{ Answer } & \multicolumn{2}{|c|}{$\begin{array}{l}\% \text { Response of } \\
\text { Post Graduate } \\
\text { aimed at seminar } \\
\text { (56) }\end{array}$} & \multicolumn{2}{|c|}{$\begin{array}{l}\% \text { Response of } \\
\text { First Year aimed } \\
\text { at seminar (42) }\end{array}$} & \multicolumn{2}{|c|}{$\begin{array}{l}\% \text { Response of } \\
\text { Second year } \\
\text { aimed at } \\
\text { seminar }(60)\end{array}$} & \multicolumn{2}{|c|}{$\begin{array}{l}\text { \% Response of } \\
\text { Third Year } \\
\text { aimed at } \\
\text { seminar }(35)\end{array}$} \\
\hline & & Before & After & Before & After & Before & After & Before & After \\
\hline \multirow{2}{*}{$\begin{array}{l}\text { Ever reported } \\
\text { suspected ADR }\end{array}$} & Yes & 25 & 27 & 7.14 & 7.14 & 23.33 & 23.33 & 22.85 & 22.85 \\
\hline & No & 75 & 73 & 92.85 & 92.85 & 76.66 & 76.66 & 77.14 & 77.14 \\
\hline \multirow{5}{*}{$\begin{array}{l}\text { Factors } \\
\text { contributing to } \\
\text { non-reporting }\end{array}$} & $\begin{array}{l}\text { Under } \\
\text { confidence }\end{array}$ & 11 & 14 & 9.52 & 0 & 21.66 & 1.66 & 8.57 & 00 \\
\hline & $\begin{array}{l}\text { Inadequate risk } \\
\text { perception }\end{array}$ & 9 & 9 & 11.90 & 0 & 10 & 3.33 & 2.85 & 8.57 \\
\hline & $\begin{array}{l}\text { Insufficient } \\
\text { training }\end{array}$ & 14 & 7 & 7.14 & 21.42 & 18.33 & 11.66 & 0 & 14.28 \\
\hline & $\begin{array}{l}\text { Unavailable } \\
\text { ADR form }\end{array}$ & 41 & 18 & 7.14 & 7.14 & 13.33 & 5 & 40 & 2.85 \\
\hline & $\begin{array}{l}\text { Lack of } \\
\text { awareness }\end{array}$ & 25 & 52 & 66.66 & 71.42 & 36.66 & 78.33 & 57.14 & 74.28 \\
\hline \multirow{2}{*}{$\begin{array}{l}\text { Have you Seen } \\
\text { ADR reporting } \\
\text { form? }\end{array}$} & Yes & 57 & 95 & 26.19 & 100 & 30 & 100 & 36.66 & 58.33 \\
\hline & No & 43 & 5 & 73.80 & 0 & 70 & 00 & 21.66 & 00 \\
\hline \multirow{3}{*}{$\begin{array}{l}\text { What needs to be } \\
\text { done with } \\
\text { suspected drug in } \\
\text { Suspected ADR? }\end{array}$} & $\begin{array}{l}\text { Withdraw } \\
\text { immediately }\end{array}$ & 52 & 88 & 9.52 & 90.47 & 55 & 85 & 42.85 & 71.42 \\
\hline & Continue & 0 & 0 & 14.28 & 0 & 11.66 & 1.66 & 5.71 & 2.85 \\
\hline & $\begin{array}{l}\text { Observe for } \\
\text { some time }\end{array}$ & 48 & 13 & 22.38 & 9.52 & 33.33 & 13.33 & 51.42 & 25.71 \\
\hline \multirow[b]{2}{*}{$\begin{array}{l}\text { Approach if ADR } \\
\text { happen }\end{array}$} & Withdraw drug & 11 & 0 & 40.47 & 4.76 & 48.33 & 11.66 & 57.14 & 14.28 \\
\hline & $\begin{array}{l}\text { Withdraw } \\
\text { immediately and } \\
\text { inform seniors }\end{array}$ & 68 & 91 & 4.76 & 92.85 & 25 & 88.33 & 37.14 & 85.71 \\
\hline \multirow{2}{*}{$\begin{array}{l}\text { Recent article } \\
\text { reading about } \\
\text { pharmaco- } \\
\text { vigilance }\end{array}$} & Yes & 29 & 46 & 11.90 & 11.90 & 21.66 & 21.66 & 17.14 & 25.71 \\
\hline & No & 71 & 54 & 88.09 & 88.09 & 78.33 & 78.33 & 82.85 & 74.28 \\
\hline
\end{tabular}

Table 2 indicate enhancement in knowledge after the seminar: $91.42 \%$ third year student gained knowledge regarding National Pharmacovigilance Programme of India which was early $51.42 \% .83 .33 \%$ first year student become aware of regional pharmacovigilance centre. Figure 1 indicate: change in attitude after transformation of knowledge, 80 to $90 \%$ students said that responsibility of underreporting is of both, health professionals and factor contributing answer to attitude based question that do you think ADRs should be reported is $100 \%$, with no change, it indicate that all the students are aware that it is important to report ADRs. 
Table 2: Knowledge.

\begin{tabular}{|c|c|c|c|c|c|c|c|c|c|}
\hline \multirow[t]{2}{*}{ Question } & \multirow[t]{2}{*}{ Answer } & \multicolumn{2}{|c|}{$\begin{array}{l}\text { \% Response of } \\
\text { Post Graduate } \\
\text { aimed at } \\
\text { seminar }(56)\end{array}$} & \multicolumn{2}{|c|}{$\begin{array}{l}\text { \% Response of } \\
\text { First Year } \\
\text { aimed at } \\
\text { seminar }(42)\end{array}$} & \multicolumn{2}{|c|}{$\begin{array}{l}\% \text { Response of } \\
\text { Second year } \\
\text { aimed at } \\
\text { seminar }(60)\end{array}$} & \multicolumn{2}{|c|}{$\begin{array}{l}\text { \% Response of } \\
\text { Third Year } \\
\text { aimed at } \\
\text { seminar }(35)\end{array}$} \\
\hline & & Before & After & Before & After & Before & After & Before & After \\
\hline \multirow{3}{*}{ Define ADR } & Correct & 73 & 93 & 38.09 & 76.19 & 65 & 80 & 51.42 & 91.42 \\
\hline & Incorrect & 22 & 7 & 45.23 & 14.28 & 30 & 20 & 48.57 & 8.57 \\
\hline & No answer & 5 & 0 & 16.6 & 9.52 & 5 & 00 & 00 & 00 \\
\hline \multirow{3}{*}{$\begin{array}{l}\text { In which year } \\
\text { National Pharmaco- } \\
\text { vigilance programme } \\
\text { started in India? }\end{array}$} & Correct & 30 & 73 & 7.14 & 73.80 & 11.66 & 88.33 & 60 & 91.42 \\
\hline & Incorrect & 66 & 18 & 69.04 & 14.28 & 80 & 10 & 25.71 & 8.57 \\
\hline & No answer & 4 & 9 & 23.80 & 11.90 & 8.33 & 1.66 & 14.28 & 00 \\
\hline \multirow{2}{*}{$\begin{array}{l}\text { Is there any such } \\
\text { ADR reporting } \\
\text { agency in our hospital }\end{array}$} & Yes & 86 & 100 & 59.52 & 100 & 70 & 100 & 85.7 & 58.33 \\
\hline & No & 14 & 0 & 40.47 & 00 & 30 & 00 & 14.28 & 00 \\
\hline \multirow{3}{*}{$\begin{array}{l}\text { What do you think } \\
\text { should be reported }\end{array}$} & $\begin{array}{l}\text { ADR and } \\
\text { medication }\end{array}$ & 55 & 77 & 73.80 & 95.23 & 70 & 96.06 & 77.14 & 82.85 \\
\hline & Side effects & 16 & 13 & 14.28 & 00 & 1.66 & 00 & 00 & 5.71 \\
\hline & Only medication & 29 & 11 & 11.90 & 4.76 & 28.33 & 5.33 & 22.85 & 11.42 \\
\hline \multirow{5}{*}{$\begin{array}{l}\text { To whom ADR } \\
\text { should be reported }\end{array}$} & Nurse & 23 & 5 & 4.76 & 9.52 & 16.66 & 3.33 & 2.85 & 8.57 \\
\hline & Pharmacist & 7 & 2 & 00 & 00 & 6.66 & 00 & 22.85 & 00 \\
\hline & Doctor & 14 & 36 & 40.47 & 38.05 & 41.66 & 11.66 & 37.14 & 20 \\
\hline & $\begin{array}{l}\text { Pharmacovigilance } \\
\text { centre }\end{array}$ & 39 & 57 & 54.76 & 52.38 & 30 & 85 & 37.14 & 71.42 \\
\hline & No Answer & 16 & 0 & 00 & 00 & 5 & 00 & 00 & 00 \\
\hline \multirow{3}{*}{ When to report ADR } & $\begin{array}{l}\text { As early as } \\
\text { possible }\end{array}$ & 38 & 80 & 33.33 & 95.23 & 61.66 & 80 & 142.85 & 94.28 \\
\hline & $\begin{array}{l}\text { Depend upon } \\
\text { seriousness }\end{array}$ & 32 & 11 & 40.47 & 4.76 & 15 & 8.3 & 37.14 & 5.71 \\
\hline & $\begin{array}{l}\text { After establishing } \\
\text { connection }\end{array}$ & 30 & 2 & 26.19 & 00 & 23.33 & 11.6 & 20 & 00 \\
\hline \multirow{2}{*}{$\begin{array}{l}\text { Is there is any law } \\
\text { regarding Pharmaco- } \\
\text { vigilance reporting }\end{array}$} & Yes & 47 & 75 & 95.23 & 95.23 & 86.66 & 88.33 & 65.11 & 71.42 \\
\hline & No & 54 & 25 & 4.76 & 4.76 & 13.33 & 11.66 & 34.28 & 28.57 \\
\hline \multirow{4}{*}{$\begin{array}{l}\text { Difference between } \\
\text { Adverse drug reaction } \\
\text { and adverse drug } \\
\text { effect }\end{array}$} & Correct answer & 55 & 72 & 30.95 & 95.2 & 31.66 & 98.33 & 77.14 & 85.71 \\
\hline & $\begin{array}{l}\text { Incomplete } \\
\text { answer }\end{array}$ & 13 & 16 & 40.47 & 00 & 40 & 00 & 14.28 & 2.85 \\
\hline & Incorrect answer & 16 & 5 & 19.04 & 94.76 & 26.66 & 1.66 & 20 & 11.42 \\
\hline & No answer & 16 & 7 & 9.52 & 00 & 1.66 & 00 & 8.57 & 00 \\
\hline \multirow{2}{*}{$\begin{array}{l}\text { Where is our regional } \\
\text { pharmaco-vigilance } \\
\text { centre located }\end{array}$} & Correct & 23 & 96 & 83.33 & 100 & 76.66 & 93.33 & 68.57 & 82.57 \\
\hline & Incorrect & 77 & 4 & 16.66 & 00 & 23.33 & 6.66 & 31.42 & 17.14 \\
\hline \multirow{4}{*}{$\begin{array}{l}\text { Name any drug } \\
\text { recently withdrawn } \\
\text { from the market due } \\
\text { to potent toxicity }\end{array}$} & Correct answer & 86 & 88 & 61.90 & 71.42 & 73.33 & 91.66 & 88.5 & 77.14 \\
\hline & $\begin{array}{l}\text { Incomplete } \\
\text { answer }\end{array}$ & 7 & 9 & 00 & 00 & 00 & 00 & 00 & 8.57 \\
\hline & Incorrect answer & 0 & 4 & 38.09 & 28.57 & 26.66 & 8.33 & 11.42 & 14.28 \\
\hline & No answer & 7 & 0 & 7.14 & 00 & 1.66 & 00 & 00 & 00 \\
\hline
\end{tabular}

\section{DISCUSSION}

Questioner based cross sectional study to assess the knowledge attitude of the future budding generation of doctors. Authors' hospital, Sir Sunderlal hospital is a tertiary care hospital catering a large number of populations of Northern India. Nodal pharmacovigilance centre was established in Department of Pharmacology in year 2011. Pharmacovigilance centre is taking an effort to improve spontaneous reporting by seminars and advertisement but there is monotonous attitude of 
professionals towards spontaneous reporting. Authors choose budding doctors for this study because they are the pillars, changing their attitude by transformation of knowledge is easy and fruitful and will give result in future. Knowledge and attitude play significant role in improving spontaneous reporting. Knowledge based question asses the current status of information they had gathered from classes, seminars and friends, internet but what are the lop hole in their knowledge which requires refinement and clarification by experts. Practise based question check their involvement in current practise of pharmacovigilance going on by nodal centre and attitude based question is make them realise their responsibility as a doctors to help in decreasing ADRs because mortality and morbidity due to ADRs is a worldwide scenario, change in attitude bring change in practise and this will happen only after transformation of correct and vivid knowledge. Knowledge based question are well answered by junior residents and Final year student this happen due to the working efforts of nodal pharmacovigilance centre, transition of knowledge in practise is important and beneficial to the society. In a study by Şencan $\mathrm{N}$, Altınkaynak $\mathrm{M}$ the responding participants, only $53.3 \%$ of physicians and almost $60 \%$ of nurses mark the correct definition of 'adverse drug reaction. It was shown that all physicians (100\%) and most of nurses (60\%) had experienced adverse drug reactions during their career, but some of them reported seen ADRs rarely and unfortunately, others had never reported. ${ }^{11}$ In present study $77 \% \mathrm{JR}$ responded that ADR and medication both should be reported which was earlier only $31 \%$. $80 \%$ JR replied that ADR should be reported as early as possible which was earlier $38 \%$. It indicate that transformation of knowledge is pillar to bring the change in practise.

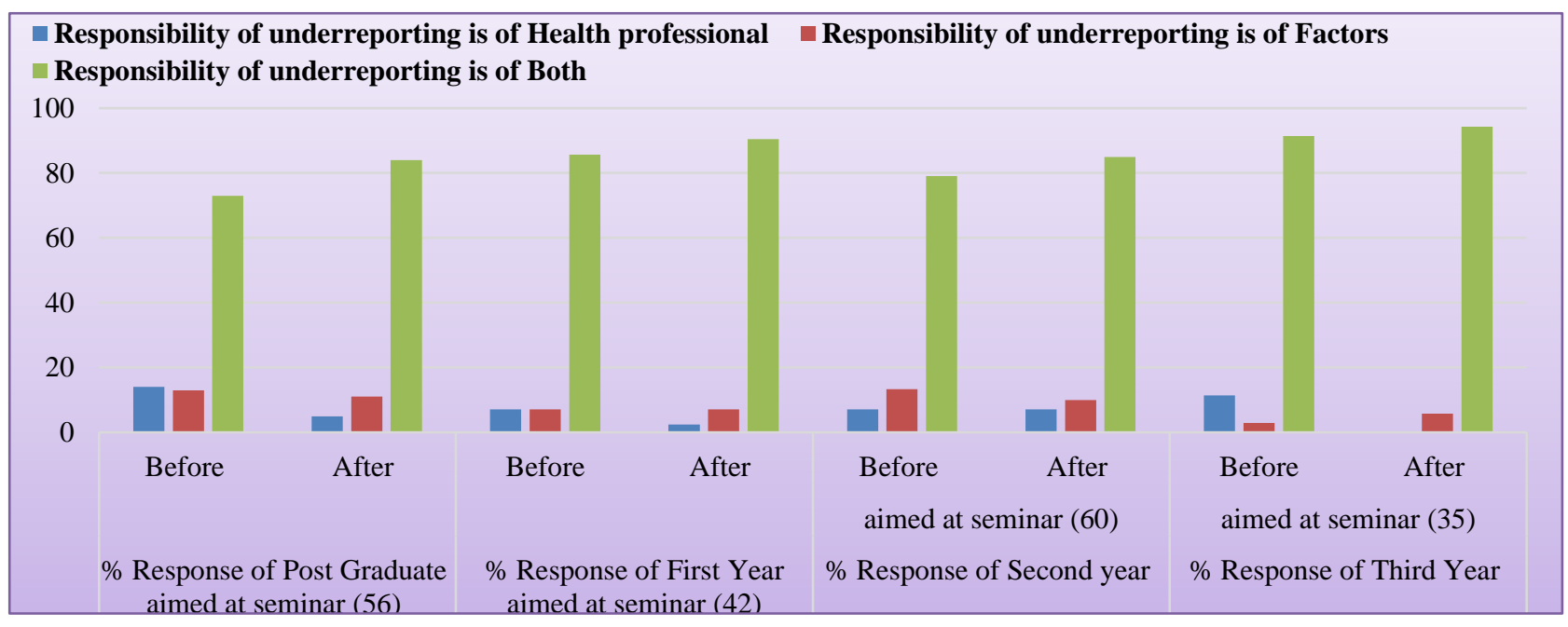

Figure 1: Attitude.

In this study authors found that $27 \%$ JR have reported ADR earlier. Knowledge play an important role to rectify the problem of under reporting. ${ }^{12}$ In a study by Ganesan S, Ganesan et al, majority of participants have good knowledge about local hospital-based ADR monitoring. The newer generation are quite techno friendly, so Pharmacovigilance App will be relevant approach to bring younger generation into the streamline of spontaneous reporting. ${ }^{13}$ This study proves that periodic awareness programme will definitely bring change and will improve the number of spontaneous reports. In the study by Fadare et al, they stated that there is a need for regular training and re-enforcement of guidelines for ADR reporting among health care personnel. Regular updates and training help in improving the Practise and number of ADR reports. ${ }^{14}$ In present study after transformation of knowledge significant improvement is seen in knowledge and attitude based question which will help to bring change in Practise in future.
This study was of short duration and not detected the improvement in number of ADR report after transformation of Knowledge. Improvement in Practise of ADR reporting is not assessed by the study. Continuation of study is planned in cooperation with Pharmacovigilance centre BHU to assess the improvement in number of reporting of ADRs.

Funding: No funding sources

Conflict of interest: None declared

Ethical approval: The study was approved by the Institutional Ethics Committee

\section{REFERENCES}

1. World Health Organization. The importance of Pharmacovigilance. 2002.

2. Kalaiselvan V, Thota P, Singh GN. Pharmacovigilance Programme of India: Recent 
developments and future perspectives. Indian $\mathbf{J}$ Pharmacol. 2016 Nov;48(6):624.

3. Bavdekar SB, Karande S. National pharmacovigilance program. Indian Pediatr. 2006 Jan 1;43(1):2

4. Kalaiselvan V, Thota P, Singh A. Current status of adverse drug reactions monitoring centres under pharmacovigilance programme of India. Indian $\mathbf{J}$ Pharm Pract. 2014 Jul;7:19-22.

5. Tandon VR, Mahajan V, Khajuria V, Gillani Z. Under-reporting of adverse drug reactions: A challenge for pharmacovigilance in India. Indian $\mathrm{J}$ Pharmacol. 2015 Jan;47(1):65.

6. Biagi C, Montanaro N, Buccellato E, Roberto G, Vaccheri A, Motola D. Underreporting in pharmacovigilance: an intervention for Italian GPs (Emilia-Romagna region). Eur J Clin Pharmacol. 2013 Feb;69(2):237-44.

7. Hazell L, Shakir SA. Under-reporting of adverse drug reactions. Drug Saf. 2006 May 1;29(5):385-96.

8. Meyboom RH, Egberts AC, Edwards IR, Hekster YA, de Koning FH, Gribnau FW. Principles of signal detection in pharmacovigilance. Drug Saf. 1997 Jun $1 ; 16(6): 355-65$.

9. van Puijenbroek EP, Bate A, Leufkens HG, Lindquist M, Orre R, Egberts AC. A comparison of measures of disproportionality for signal detection in spontaneous reporting systems for adverse drug reactions. Pharmacoepidemiol Drug Saf. 2002 Jan;11(1):3-10.

10. Sachs RM, Bortnichak EA. An evaluation of spontaneous adverse drug reaction monitoring systems. Am J Med. 1986 Nov;81(5B):49-55.
11. Şencan N, Altınkaynak M, Ferah I, Özyıldırım A, Ceylan E, Clark P. The knowledge and attitudes of physicians and nurses towards advers event reporting and the effect of pharmacovigilance training: a hospital experience. Hacettepe Uni J Faculty Pharma. 2010 Jan;30(1):25-40.

12. Pérez García M1, Figueras A. The lack of knowledge about the voluntary reporting system of adverse drug reactions as a major cause of underreporting: direct survey among health professionals. Pharmacoepidemiol Drug Saf. 2011 Dec;20(12):1295302.

13. Ganesan S, Vikneswaran G, Reddy KC, Subrahmanyam DK, Adithan C. A survey on knowledge, attitude and practice of pharmacovigilance towards adverse drug reactions reporting among doctors and nurses in a tertiary care hospital in South India. J Young Pharm. 2016 Oct $1 ; 8(4): 471-6$.

14. Fadare JO, Enwere OO, Afolabi AO, Chedi BA, Musa A. Knowledge, attitude and practice of adverse drug reaction reporting among healthcare workers in a tertiary centre in Northern Nigeria. Trop J Pharmaceut Res. 2011;10(3).

Cite this article as: Giri KR, Palandurkar KM, Giri RR. A cross sectional study of knowledge, practice and attitude of medical professionals regarding pharmacovigilance function. Int J Basic Clin Pharmacol 2018;7:1752-7. 